\title{
An employer brand predictive model for talent attraction and retention
}

\author{
Authors: \\ Annelize Botha ${ }^{1}$ \\ Mark Bussin ${ }^{1}$ \\ Lukas de Swardt ${ }^{1}$ \\ Affiliations: \\ ${ }^{1}$ Department of Industrial \\ Psychology and People \\ Management, University of \\ Johannesburg, South Africa \\ Correspondence to: \\ Mark Bussin \\ Email: \\ drbussin@mweb.co.za \\ Postal address: \\ PO Box 2334, Saxonwold \\ 2132, South Africa \\ Dates: \\ Received: 03 June 2011 \\ Accepted: 15 Sept. 2011 \\ Published: 14 Nov. 2011 \\ How to cite this article: \\ Botha, A., Bussin, M., \& \\ De Swardt, L. (2011). An \\ employer brand predictive \\ model for talent attraction \\ and retention. SA Journal \\ of Human Resource \\ Management/SA Tydskrif vir \\ Menslikehulpbronbestuur, \\ 9(1), Art. \#388, 12 pages. \\ http://dx.doi.org/10.4102/ \\ sajhrm.v9i1.388
}

(C) 2011. The Authors.

Licensee: AOSIS

OpenJournals. This work

is licensed under the

Creative Commons

Attribution License.
Orientation: In an ever shrinking global talent pool organisations use employer brand to attract and retain talent, however, in the absence of theoretical pointers, many organisations are losing out on a powerful business tool by not developing or maintaining their employer brand correctly.

Research purpose: This study explores the current state of knowledge about employer brand and identifies the various employer brand building blocks which are conceptually integrated in a predictive model.

Motivation for the study: The need for scientific progress though the accurate representation of a set of employer brand phenomena and propositions, which can be empirically tested, motivated this study.

Research design, approach and method: This study was nonempirical in approach and searched for linkages between theoretical concepts by making use of relevant contextual data. Theoretical propositions which explain the identified linkages were developed for purpose of further empirical research.

Main findings: Key findings suggested that employer brand is influenced by target group needs, a differentiated Employer Value Proposition (EVP), the people strategy, brand consistency, communication of the employer brand and measurement of Human Resources (HR) employer branding efforts.

Practical/managerial implications: The predictive model provides corporate leaders and their human resource functionaries a theoretical pointer relative to employer brand which could guide more effective talent attraction and retention decisions.

Contribution/value add: This study adds to the small base of research available on employer brand and contributes to both scientific progress as well as an improved practical understanding of factors which influence employer brand.

\section{Introduction}

\section{Key focus of the study}

Why would someone really good at their job want to join your company? And how will you keep them for more than a few years? Against the background of these contemporary questions, and at a time when seeking talent in the ever shrinking global talent pool has become an international crusade, companies are uncertain as to what talent attraction and retention decisions they should be making (Armstrong, 2007; Bussin, 2007; Crous, 2007; Leonardi, 2007; Minchington, 2006).

A growing body of research evidence supports the relationship between employer brand and the attraction and retention of talent (Cheese, Thomas \& Craig, 2007; Crous, 2007; Minchington, 2010; Willock, 2005). Even though it is fairly customary amongst larger companies to use employer brand to attract and retain talent (Dell, Ainspan, Bodenberg, Troy \& Hickey, 2001), companies are ineffective in developing, maintaining or realigning their employer brand efforts correctly thereby losing out on a powerful talent attraction and retention tool (Cheese et al., 2007; Minchington, 2006).

Most employer brand research focuses on the possible relationship between various employer brand concepts and talent attraction and retention, with limited attempts to build a coherent employer brand model that can successfully predict talent attraction and retention. The key focus of this study is to integrate relevant employer brand concepts, or employer brand building 
blocks, in an employer brand predictive model that can be empirically validated to predict talent attraction and retention.

\section{Background to the study}

In an era where skills and knowledge of employees are amongst the main competitive enablers, organisations cannot ignore the significance of attracting and retaining talented people (Hallén, 2007; Minchington, 2010; Mohaptra, 2005; Prinsloo, 2008).

The new economy is characterised by a volatile talent demand-supply equation set against erratic attrition trends and boundless cutthroat competition, and organisations have never had a tougher time in finding, managing and nurturing talent (Cheese et al., 2007; Mohaptra, 2005).

The impact of talent shortage obstructs organisational efforts to execute against growth strategies thereby rendering sustainability threats to organisations and straining economic growth (Boshard \& Louw, 2010; Charest, 2011; Ingham, 2006; Prinsloo, 2008). Corporate leaders and their human resource functionaries are moving towards placing a high premium on employer brand as a critical success factor for companies striving for competitive advantage in the talent war (Cheese et al., 2007; Crous, 2007; Minchington, 2006). This observation is confirmed in a recent global survey by Deloitte LLP (2010) who found that the importance of employer brand appears to have the attention of companies with retention plans as more than seven in ten (72\%) will increase their focus on their employer brand in the year to come.

\section{Purpose of the study}

Against the background explained earlier, the intent of this study is to provide managers and human resource functionaries an employer brand model to guide more effective talent attraction and retention decisions that could augment overall business performance, whilst the qualitative model-building approach of this article is aimed at bringing conceptual coherence to the employer brand domain thereby adding value to scientific progress.

\section{Trends from the research literature}

The transition from the industrial era to the knowledge era has changed the employer-employee relationship paradigm, and the supply and demand curve for talent is becoming increasingly favoured towards the talented employee. The quest to win the talent war confronts companies around the world to realign their employer brand efforts in a bid to mitigate talent limitations (Deloitte LLP, 2010; Minchington, 2006).

Employer brand is associated with an organisation's differentiated attractiveness in terms of functional, economic and psychological benefits (Ambler \& Barrow, 1996; Corporate Leadership Council, 2007; Donath, 2001; Minchington, 2006) and a strong employer brand acts as an enticement for talent in the current marketplace (Rosethorn, 2009; Willock, 2005). Talent refers to an individual's differentiated potential or ability to execute against the organisation's growth strategy and is a term that is much talked about in the contemporary era, however, effective talent attraction and retention remains an elusive business feat (Boshard \& Louw, 2010; Charest, 2011; Cheese et al., 2007; Leonardi, 2007; Personnel Today, 2008; Prinsloo, 2008).

Although research evidence supports the relationship between employer brand and the attraction and retention of talent, limited attempts have been undertaken to identify employer brand concepts in the format of an employer brand model, that predicts talent attraction and retention (Armstrong, 2007; Backhaus \& Tikoo, 2004; Crous, 2007; Dell et al., 2001; Jenner \& Taylor, 2007; Martin, 2007; Minchington, 2010; Willock, 2005).

These trends highlighted the need for empirically validated employer brand models that can predict effective talent attraction and retention efforts, and provide a coherent view that explains employer brand concepts contributing to talent attraction and retention.

\section{Problem statement and research objectives}

A research of current literature has revealed that the global talent pool is shrinking and organisations are uncertain as to what talent management decisions they should be making (Armstrong, 2007; Bussin, 2007; Crous, 2007; Leonardi, 2007b; Minchington, 2006). Research evidence confirms the relationship between employer brand and the attraction and retention of talent (Crous, 2007; Dell et al., 2001; Minchington, 2010; Willock, 2005), however, Minchington (2006) claims that many organisations are not developing or maintaining their employer brand correctly, and talent shortages can render organisations vulnerable in terms of competitive sustainability (Boshard \& Louw, 2010; Charest, 2011; Prinsloo, 2008).

What are the key building blocks of an employer brand predictive model that can be empirically validated to effectively predict talent attraction and retention, and contribute to both favourable positioning in the quest for talent as well as competitive sustainability? This is the main question that this article aims to address.

The secondary objectives, derived from the problem statement, are to describe the theory that constructs each building block, and integrate these building blocks to form a conceptual coherence that depicts employer brand relative to talent attraction and retention.

\section{Value-add of the study}

The quest to win the talent war has expanded to employer brand issues deemed to be related to the attraction and retention of talented staff (Bussin, 2007; Crous, 2007; Dell et al., 2001; Hallén, 2007; Lawler, 2000; Minchington, 2010; Prinsloo, 2008; Zingheim \& Schuster, 2000). The impact 
of persistent talent shortage could render organisations incapable of growth, and detract from their efficacy in gaining or sustaining a winning edge, thus ultimately jeopardising their survival (Boshard \& Louw, 2010; Charest, 2011; Prinsloo, 2008). The collapse of organisations adversely affects the macroeconomic environment as it counters sustainable economic growth, which in turn negatively influences a better quality life for all.

The need for employer brand models, which could be empirically tested to successfully predict talent attraction and retention, motivated this study. Benefits of models are underscored by Mouton (2001) who states models allow one to make predictive claims under certain conditions, and bring conceptual coherence to a domain of science thereby simplifying our understanding of the world. Thus, models limit, isolate, simplify and systematise the domain that is investigated, and provide explanation sketches and the means for making predictions (Jordaan, 2007).

The aim of this study is to present an employer brand predictive model with building blocks that denote an integrated approach which shapes and influences the total employer brand process relative to talent attraction and retention. It is hoped that this employer brand predictive model will provide managers and human resource functionaries guidance on more effective employer brand decisions that will mitigate talent limitations and bolster overall business performance.

\section{An outline of the structure of the rest of the article}

The remainder of the article is structured as follows: a brief literature review is followed by the research design, the results of the research are presented under findings, and a discussion features the last section of the article.

\section{Current theoretical perspectives}

Based on a critical review of current literature which searched for linkages between theoretical concepts, the following employer brand concepts are isolated due to referenced researchers' significance attributed to these concepts in relation to talent attraction and retention.

\section{Needs}

Research findings by Milkovich and Newman (2008) confirm that job candidates are attracted to companies with benefits that fit their inherent preferences or needs, whilst research findings by the Corporate Leadership Council (2002) emphasise the alignment between the Employee Value Proposition (EVP) and employee needs constitutes an offer fit. Employee or target group needs include functional, economic and psychological preferences (Minchington, 2010; Moroko \& Uncles, 2009; Sartain \& Shumann; 2006). These findings are supported by Maslow's Theory of Human Motivation and McClelland's Acquired-Needs Theory that claim a person's motivation is shaped by needs and people are attracted to a source that could fulfil their needs (Armstrong, 2007; McClelland, 1961). The application of market segmentation techniques are recommended as the most optimal way to segment the employee population, and determine the most appropriate employer value that will differentiate the employee offering and address the needs of the target population (Kotler, 2007; Minchington, 2010; Moroko \& Uncles, 2009; Walker, 2007). Market segmentation allows for targeted marketing of stakeholders based on insight into their specific needs and are segmented in geographic segments, demographic segments, psychographic segments and behaviouristic segments (Kotler, 2007; Walker, 2007).

It thus seems probable that insight into the target group's needs and preferences could add impetus to the attractiveness of the employer brand; such insight could enhance alignment between functional, economic and psychological benefits on offer and the needs of the target group but should also enhance ethics and fairness and mitigate possible perceived discrimination:

Proposition 1: The target group's needs, relative to business strategy, influences employer brand.

\section{A differentiated Employer Value Proposition}

A differentiated Employer Value Proposition (EVP) adds impetus to the employer brand; it describes a desired future state relative to the Company's strategic objectives and preferred culture (Kochanski, 2004), and is informed by a thoughtfully designed total rewards strategy (Armstrong, 2007; Blanchard, 2007; Bussin, 2007; Corporate Leadership Council, 2007; Deloitte Consulting LLP, 2008; Lawler, 2000; WorldatWork, 2007; Zingheim \& Schuster, 2000). Differentiated EVPs leverage core differentiating talent attraction aspects, and allows for targeted employer brand marketing efforts (Corporate Leadership Council, 2002; Kochanski, 2004; Minchington, 2010; Purkayastha, 2006; Sartain \& Schumann, 2006). A differentiated EVP provides a succinct and clear distillation of what sets a company apart as an employer, and is defined as the unique set of attributes and benefits that will motivate target candidates to join a company and current employees to stay (Sartain \& Schumann, 2006). The EVP is unique and based within a human capital strategy or people strategy, which is aligned to business strategy (Kochanski, 2004), and is informed by five main elements, namely: work environment and affiliation (this includes values, culture, quality of colleagues, managers and leaders), work content including challenging work and work-life balance, benefits including development and career growth (indirect financial reward), and remuneration (direct financial reward), (Corporate Leadership Council, 2002; Michaels, Handfield-Jones \& Axelrod, 2001; Munsamy \& Bosch Venter, 2009; Sartain \& Schumann, 2006). According to Munsamy and Bosch Venter (2009), organisations are at risk of turnover when their EVP is perceived less competitive than that of other organisations.

From an overview of the literature it seems plausible that a differentiated EVP plays a role in employer brand success:

Proposition 2: A differentiated EVP influences the employer brand. 


\section{People strategy}

Employer branding relates to the application of branding principles to human resource management and successful employer branding is defined as an employer's targeted people management strategy to deliver on the employer brand promise (Backhaus \& Tikoo, 2004; Glen, 2007; Minchington, 2006; Tüzüner \& Yüksel, 2009). Employer branding encompasses an organisation's values, systems, policies and behaviours towards the aim of attracting, motivating and retaining current and potential employees (Wilden, Gudergan \& Lings, 2006). The delivery on the employer brand promise requires alignment with the identified needs of the specific target population, as well as alignment with the corporate and consumer brand (Barrow \& Mosley, 2005; Kotler, 2007; Milkovich \& Newman, 2008; Walker, 2007).

Both the employer brand employee platform as well as the employer brand strategic platform informs the people strategy to deliver on the employer brand promise (Minchington, 2010). The employer brand employee platform refers to aspects such as recruitment and induction, remuneration and benefits, career development, research, reward and recognition, communication, work environment and performance management (Minchington, 2010). The employer brand strategic platform encompasses aspects such as mission, vision, values, corporate reputation and culture, policies, leadership and management competence and innovation (Minchington, 2010). Any gap in the organisation's ability to deliver on the employer brand promise will negatively impact the employer brand and the organisation as a whole (Backhaus \& Tikoo, 2004; Barrow \& Mosley, 2005; Deloitte LLP, 2010; Minchington, 2006).

From the initial literature review it seems plausible that both the employer brand employee platform as well as the employer brand strategic platform should inform the people management strategy to ensure an organisation can deliver on its employer brand promise:

Proposition 3: A peoplestrategy informed by the employer brand employee platform as well as the employer brand strategic platform influences the employer brand.

\section{Brand consistency}

The total portfolio of brands needs to be aligned in organisational strategy as each brand subset has an impact on the other, and the essence of the corporate and consumer brand should be reflected in the essence of the employer brand to ensure consistency in delivery on the portfolio of brand promises (Barrow \& Mosley, 2005; Fraser, 2009; McKinsey, 2005; Minchington, 2010). Organisations with superior employment offerings are those whose employer brand matches their corporate and consumer brand(s), and where the value proposition the business articulates is reflected by the actions of all people, at all levels of the business, at all times (Fraser, 2009; Minchington, 2010).

Based on the initial literature review it is postulated that one of the key components of a great employer brand is consistency in delivery on the portfolio of brand promises:
Proposition 4: Consistency in the portfolio of brands influences the employer brand.

\section{Communication}

The aim of employer brand communication, or employer brand voice, is to create an understanding of the employer brand, and the employer brand voice must be consistent with all organisational marketing efforts in order to be effective (Duraturo, 2010; Edwards, 2005; Lloyd, 2002; Minchington, 2010; Rosethorn, 2009; Willard, 2010). Employer brand communication is defined as honest and authentic employer brand messages about employment promises which could be delivered upon through an organisation's employer branding (people management) practices (Backhaus \& Tikoo, 2004; Minchington, 2010). The importance of coherent employer brand communication efforts is encapsulated in Minchington's (2010) observation that when internal communication, marketing and Human Resources (HR) departments fail to collaborate on the company's employer brand strategy, the result is often nothing more than a HR project that burns cash and creates employee cynicism. Various online, as well as off line communication channels could be applied to convey targeted employer brand messages to the target audience; these channels should enable instant connectivity with organisations, as well as rapid response from organisations (Duraturo, 2010; McKinsey, 2005; Minchington, 2010).

From the initial literature review the significance of communication relative to employer brand converges, and the following proposition is made:

Proposition 5: Communication influences the employer brand.

\section{Metrics}

It is not one of the aims of this study to determine the influence of employer brand measurement on the effectiveness of employer brand. One of the intensions is to rather investigate the measurement of $\mathrm{HR}$ employer branding (people management) efforts as a possible influencer of employer brand. Higgins (2010) and Lockwood (2006) claim that meaningful and value adding metrics has the potential to support delivery on the employer brand promise as it measures HR employer branding (people management) efforts (Backhaus \& Tikoo, 2004; Barrow \& Mosley, 2005; Edwards, 2005; Minchington, 2010). Higgins (2010) from the Watson Wyatt Group suggests that employer branding could be measured by populating the HR scorecard with employer brand metrics relevant to people management practices which will deliver on the EVP.

\section{Research design Research approach}

The research paradigm adopted for this study is nonempirical and a model building approach was followed. This approach has been adopted based on the fact that this study proposes an employer brand predictive model which represents 
key building blocks associated with employer brand that influence talent attraction and retention. A key benefit of conceptual model building is its potential to accurately represent phenomenon through a set, or sets, of statements (Mouton, 2001; Torraco, 1997; Welman \& Kruger, 2001).

In this positivist assumption research approach phenomena are explained by identifying main concepts from theory construction, and by searching for linkages between concepts, which according to Cooper and Schindler (1998) and Mouton (2001), allows one to make predictive claims and bring conceptual coherence by explaining links between propositions. An inductive form of theory construction was applied whereby sets of postulates or propositions were formulated about the phenomena. Theoretical propositions were inductively derived from the sets of postulates until comprehensive sets of theoretical propositions were developed which can be tested empirically.

\section{Research method}

The research method is presented under the following subheadings: targeted body of literature, gathering the data, analysis of the data and presentation of the data.

\section{Targeted body of literature}

This study aims at developing a new model to be tested in future research for causal links between relative employer brand propositions. In order to build the model the unit of analysis was quantitative and textual data relating to employer brand issues were accessed through literature searches. Data were found in text books which are located in academic libraries of the University of Johannesburg (UJ), University of Pretoria and the University of South Africa (UNISA), and in journals located in various databases such as Emerald, EBSCOhost and SAePublications. These databases were selected based on their accessibility and relevant coverage of multidisciplinary business, HR and management data, and were accessed through web portals, for example, http://www.uj.ac.za/library. The UJ web portal was also used to trace and extract relevant data from electronic master's theses and doctorate dissertations. Database searches of professional organisations such as Corporate Leadership Council (CLC), Deloitte LLP, Employer Brand International (EBI), and Collective Learning Australia (CLA) were also conducted. The targeted literature was mainly restricted to English textual data found in research theses and/or dissertations, journal articles and text books relative to employer brand issues published between 2002 and 2011. The selected date range coincides with the onset of the awareness of talent shortage, the high premium that organisations have placed on employer brand as a competitive advantage in the talent war during recent years and the dissemination of relevant textual data during this period.

\section{Gathering the data}

Keywords derived from the isolated employer brand concepts identified in the initial literature survey, served as guidance to narrow down the textual data search to identify articles of relevance. These keywords include employer brand, target group needs and/or segmentation, differentiated $\mathrm{EVP}$, people management strategy and/or delivery on the employer brand promise, brand consistency, employer brand communication, and employer branding metrics and/ or measures. The selection criteria for relevant data consisted of published research articles and studies, related to the keywords that were written in English from 2002 to 2011. The aim was to focus and isolate data that indicated descriptions and/or correlations between variables which were applied in formulating postulates or propositions. Relevant data were isolated in a tabular tracking sheet, as well as data that were eliminated as their content proved no relevance to the problem definition and the purpose of the study.

\section{Analysis of the data}

A total of 129 manuscripts were reviewed by means of the keywords to identify data of relevance. The location of relevant textual data was accurately noted and recorded to ensure that the results could be replicated by accessing the same data bases. Data were analysed by means of a thematic analysis approach whereby 24 research articles were selected and summarised in a tabular format detailing the author, study purpose, sample and setting, method of analysis and key findings. These 24 research articles were selected based on their research findings that indicated correlations and/or descriptions between keywords. The data sets of variables relative to the keywords that demonstrated a coherent linkage between theoretical concepts were analysed through inductive thematic analysis to derive at theoretical propositions which are postulated for purpose of further empirical research.

\section{Presentation of the data}

The findings of the research will be presented under keyword headings derived from the relevant employer brand concepts that were identified in the literature review.

\section{Results \\ Research findings}

The research review findings are discussed under the following headings.

\section{Target group needs}

Target group needs are defined as the differentiated needs of the target population (Minchington, 2010; Walker, 2007) that would require marketing segmentation techniques to provide insight into the differentiated needs (Moroko \& Uncles, 2009; Sartain \& Schumann, 2006) enabling companies to offer benefits in alignment with these needs and execute attraction and retention strategies more effectively (Corporate Leadership Council, 2002; Milkovich \& Newman, 2008; Moroko \& Uncles, 2009).

Four studies were found to be relevant. Moroko and Uncles (2009) findings suggested that the application of marketing segmentation techniques enhances employer branding 
efforts and boosts the effectiveness of the strategy as a whole. Tüzüner and Yüksel (2009) found that turnover increased and job satisfaction decreased where no attention was paid to various needs of employees whilst Mortensen (2010) found that employer brand and talent attraction and retention can be augmented when organisations segment prospective talent needs. Berthon, Ewing and Hah (2005) observed that successful employer branding relied on understanding factors contributing toward employer attractiveness, and cross-cultural differences influenced diverse ways in which employer attractiveness was perceived.

\section{Differentiated Employer Value Proposition}

For the purpose of this study a differentiated Employer Value Proposition (EVP) is defined as the distinctive total employment experience (Kochanski, 2004; Minchington, 2010; Purkayastha, 2006; Sartain \& Schumann, 2006), or unique financial and nonfinancial offering (Corporate Leadership Council, 2007) provided by an organisation in return for skills, capabilities and experiences an employee brings to the organisation (Minchington, 2006); it helps to establish a differentiated positioning relative to other employers (McKinsey, 2006; Minchington, 2006; Sartain \& Schumann, 2006) by adding impetus to the employer brand (Kochanski, 2004).

One study demonstrated a linkage relative to investigating the impact of a differentiated EVP. The findings of Knox and Maxwell (2009) reflect that employees in five different organisations consider different EVP attributes to be attractive; thereby confirming the importance of a distinctive EVP which could add impetus to an organisation's employer brand.

\section{People strategy}

Within the context of this study the people strategy is informed by the employer brand platforms (Minchington, 2006), and relates to the application of branding principles to human resource management to enable the organisation to deliver on the employer brand promise (Backhaus \& Tikoo, 2004; Glen, 2007; Minchington, 2006; Tüzüner \& Yüksel, 2009).

Eight relevant studies were identified regarding selection. Punjaisri and Wilson (2007) observed a significant need for the coordination of marketing and HR practices within an organisation to establish and reinforce the alignment of employees' behaviours with the brand values. These practices include recruitment and induction, communication, and training. Findings by Hodes (2006) validated the importance of building the employer brand from the inside out to ensure delivery on the employer brand promise and that the delivery on the employer brand promise is embedded in all HR activity, strategy and outputs. These findings of Hodes (2006) were reiterated by research findings of Kgobe (2010) who found employer branding practices close gaps between what employees expect and what the organisation delivers. Studies by Schumann (2006) confirmed prospective employees are attracted to employer brands they associate with, and expect the company to deliver on the anticipated employer brand promise, or on the 'what's in it for me' (i.e. what is in it for the employee). Schumann (2006) concludes that the employer brand must be articulated in an organisation's actions and values which are embedded in people management practices driven from the inside out. Research results by Boyd and Sutherland (2005) confirmed the importance of a people strategy with clearly articulated people management practices that will obtain employees' commitment to living the employer brand and delivering on the employer brand promise. Based on an extensive literature review the article by Hughes and Rog (2008) concluded that the inclusion of an employer brand and a differentiated EVP was important for the successful implementation of talent management, and that internalisation of the employer brand would depend on the organisation's people management practices. Research conducted by Deloitte LLP (2010) and by CareerBuilder (2008), which involved the analyses of 265000 respondents, confirmed that in order for companies to attract and retain talent, they must be able to continuously deliver on the employer brand promise. Research findings by Minchington (2010) and Sutherland and Karg (2002) verified the importance of considering both the employer brand employee platform, as well as the employer brand strategic platform when implementing employer of choice people management (employer branding) practices. These studies confirmed that a culture of career growth and innovation, challenging work, pay for performance, and a values driven organisation are attributes which knowledge workers view as important when looking for the ideal employer.

\section{Brand consistency}

For the purpose of this study brand consistency refers to a coherent relationship between the employer brand, corporate brand and consumer brand where the total portfolio of brands are aligned to ensure clarity in strategic positioning and consistency in the delivery on the portfolio of brand promises (Barrow \& Mosley, 2005; Fraser, 2009; Minchington, 2010).

Four relevant studies were found. Findings by Freeman and Knox (2006) confirmed a correlation between an attractive employer brand image and likelihood to apply for a job, and the importance for an integrated approach between internal marketing and external marketing to develop a more congruent employer brand. Research by King and Grace (2008) confirmed that the alignment of the EVP, or 'what's in it for $m e^{\prime}$ as an employee, with the business or customer brand enhanced employee engagement, and commitment to the business or customer brand. Gapp and Merrilees (2006) found misalignment between external brand (the promise) and internal brand (delivering on the promise) damaged the trust between employees and senior management, and resulted in discord between strategic plans and operational activities. Mosley's (2007) article presented two key conclusions: firstly, the practice of managing the links between brand, culture and customer experience has evolved 
significantly over recent years; employer brand should be consistent to the overall brand message, and the notion of employer brand management completes a journey that began with a disciplined approach to managing the total brand experience. Secondly, through an application of the same principles to service brands and customer management, employer brand should be managed during touch points on the employer brand employee platform, and during actual experience of the employer brand strategic platform.

\section{Communication of the employer brand}

Within the framework of this study communication of the employer brand refers to an employer brand voice (Duraturo, 2010) that reflects honest and authentic employer brand messages (Backhaus \& Tikoo, 2004; Barrow \& Mosley, 2005; Minchington, 2010) which are consistent with all organisational marketing efforts (Duraturo, 2010; Minchington, 2010; Willard, 2010) and channelled effectively to reach the target audience (Bhattacharya, 2009; Duraturo, 2010; Minchington, 2010).

Five relevant studies were found. Kapoor (2010) found communication of key employer brand messages remained one of the top three challenges in managing an employer brand whilst Bowd (2006) observed the communication of employer brand messages was key in order to positively impact employer brand perception. Research findings by Watson Wyatt (2005) indicated that organisations that are highly effective communicators experienced strong employer brand strength, high levels of engagement and 20\% lower turnover rates than their peers. Organisations with excellent communications performance had metrics in place to gauge the impact of their communications programmes. Knox and Bickerton's (2008) findings emphasised the importance of clearly communicating the brand proposition, and also ensuring that these communications are reinforced by organisation behaviours and supported by processes which deliver on the promise. A conceptual model building approach by Miles and Mangold (2004) illustrated the importance of consistently delivering the employer brand message at all the employee touch points (recruitment, orientation, communication, shared services, performance and development, reward and recognition), and that employees should experience employer brand through every day behaviours, values, management competencies and leadership competencies.

\section{Human Resources employer branding metrics}

Within the context of this study Human Resources (HR) employer branding metrics refer to the measurement of HR employer branding (people management) efforts (Fernon, 2008; Higgins, 2010) which are informed by both the employer brand employee platform and the employer brand strategic platform (Minchington, 2010) to ensure people management practices deliver on the EVP and employer brand promises (Higgins, 2010; Lockwood, 2006).

No significant employer branding metrics research results were found. Only one article was found to be of relevance given the context of this study. An article by Higgins (2010) underscored the importance of measuring HR employer branding efforts to ensure delivery on the employer brand promise by designing an HR scorecard which is context specific. Both leading and lagging indicators should be included in employer branding measures to ensure business is supplied by relevant and useful knowledge rather than historical information, and delivery on the employer brand promise.

\section{Discussion}

At a time when seeking talent in the ever shrinking global talent pool has become an international crusade (Armstrong, 2007; Bussin, 2007; Crous, 2007; Leonardi, 2007; Minchington, 2006), the quest to win the talent war has expanded to HR best practice, employer brand, reward, recognition and benefits - all issues related to the attraction and retention of talented staff (Crous, 2007).

Employer brand is defined as the organisation's differentiated attractiveness in terms of functional, economic and psychological benefits that are identified with the image of the employing company (Ambler \& Barrow, 1996; Corporate Leadership Council, 2007; Donath, 2001; Minchington, 2006).

Although a growing body of evidence supports the relationship between employer brand and the attraction and retention of talent (Crous, 2007; Dell et al., 2001; Minchington, 2010; Willock, 2005), limited attempts to build an employer brand model to predict talent attraction and retention has been undertaken (Armstrong, 2007; Backhaus \& Tikoo, 2004; Jenner \& Taylor, 2007; Martin, 2007). The purpose of this study was to explore the current state of knowledge about employer brand and to determine the key building blocks of an employer brand predictive model that can be empirically validated to effectively predict talent attraction and retention.

The benefit of the study's model building approach systemises the employer brand domain and brings conceptual coherence to a domain of science. Another contribution of the study is providing managers and human resource functionaries an integrated approach which shapes and influences the total employer brand process relative to talent attraction and retention. The following discussion synthesises linkages in literature between theoretical concepts and explains causal links between propositions.

\section{Summary of findings}

This section starts by synergising the findings and the premise of this study is explored by detailing whether the literature review reiterates, or differs from, the findings. The propositions are set in the discussion and mirror the flow of the employer brand predictive model which is depicted in the latter part of this section. This section concludes by suggesting theoretical implications and practical implications, presenting limitations as well as suggestions for future research. 


\section{Target group needs}

Research findings indicated that the target group needs dimension had a positive relation to employer attractiveness, employer brand efforts and the augmentation of talent attraction and retention (Berthon, Ewing \& Hah, 2005; Moroko \& Uncles, 2009; Mortensen, 2010; Tüzüner \& Yüksel, 2009).

The aforementioned finding was reiterated by target group needs related literature that found people are attracted to a source that could fulfil their needs (Armstrong, 2007; Minchington, 2010; Walker, 2007), and that segmentation tools and techniques assist in adapting the talent brand message for each segment based on insight into the target group's needs and preferences (Moroko \& Uncles, 2009; Sartain \& Schumann, 2006). Research studies done by the Corporate Leadership Council (2002) and Milkovich and Newman (2008) reveal job candidates are attracted to companies with a good offer fit and benefits that fit their inherent preferences.

However, the application of market segmentation to the employer brand context is not without limitations. There are, for example, legal barriers to segmenting current and potential employees on the base of race, gender, age, ethnicity or disability; this potential barrier could be negated if companies invest in the gathering, holding and analysis of quality employee needs data that informs segmentation approaches within the context of fairness and the broader company strategy (Moroko \& Uncles, 2009).

The synthesis in linkage between research findings and the literature review supports the first proposition (P1) of this study which postulates that target group's needs, relative to business strategy, influences employer brand.

\section{Differentiated Employer Value Proposition}

Research findings by Knox and Maxwell (2009) reflected that employees in five different organisations considered different Employer Value Proposition (EVP) attributes to be attractive; and confirmed the importance of a unique and distinctive EVP which added impetus to the employer brand.

The aforementioned research finding was reiterated in relevant literature that suggests the EVP helps to establish a differentiated positioning relative to other employers (Deloitte LLP, 2010; McKinsey, 2006; Minchington, 2006; Sartain \& Schumann, 2006). Kochanski (2004) cites the importance of a distinctive EVP in the best places to work lists. A distinctive EVP adds impetus to the employer brand (Kochanski, 2004), and leverages core differentiating talent attraction aspects by enabling targeted employer brand marketing efforts (Kochanski, 2004; Purkayastha, 2006). A differentiated EVP motivates target candidates to join a company and current employees to stay (Brand Learning, 2009). The linkage between relevant findings supports the second proposition (P2) and implies that a differentiated EVP influences the employer brand.

\section{People strategy}

Within the context of this study the people strategy relates to the application of branding principles to HR management to enable the organisation to deliver on the employer brand promise (Backhaus \& Tikoo, 2004; Glen, 2007; Minchington, 2006; Tüzüner \& Yüksel, 2009).

Empirical research findings indicated that delivery on the employer brand promise was embedded in all HR activity, strategy and outputs (Hodes, 2006; Kgobe, 2010), and the internalisation of the employer brand depended on the organisation's people management practices (Boyd \& Sutherland, 2005; Hughes \& Rog, 2008; Punjaisri \& Wilson, 2007; Schumann, 2006) which were informed by elements of both the employer brand employee platform as well as the employer brand strategic platform (Sutherland \& Karg, 2002).

Literature suggests that an organisation's people strategy delivers on the employer brand promise where the value proposition that the organisation articulates is reflected by the actions of all people (Backhaus \& Tikoo, 2004; Barrow \& Mosley, 2005; CareerBuilder, 2008; Glen, 2007; Minchington, 2006). According to Minchington (2010), both the employer brand employee platform as well as the employer brand strategic platform should inform the people strategy to ensure the implementation of people management practices which will abet delivery on the employer brand promise.

The reiteration in linkage between empirical research findings and relevant literature sustains the third proposition (P3) and suggests that a people strategy, informed by the employer brand employee platform and the employer brand strategic platform impacts on employer branding practices which consecutively influences the employer brand.

\section{Brand consistency}

Research findings by Freeman and Knox (2006) confirmed the importance for an integrated approach between internal marketing and external marketing to develop a more congruent employer brand, whilst King and Grace (2008) found that the alignment of the EVP with the business and/or customer brand enhanced employee engagement, and commitment to the business and/or customer brand. The finding of Gapp and Merrilees (2006) confirmed that misalignment between external brand (the promise) and internal brand (delivering on the promise) damaged the trust between employees and senior management, and resulted in discord between strategic plans and operational activities. All of the mentioned findings correspond with Mosley's (2007) conclusion that employer brand should be consistent to the overall brand message to ensure delivery on the employer brand promise.

Literature affirmed that an organisation with a superior employment offering is one whose employer brand matches their corporate and consumer brand(s) (Fraser, 2009; Minchington, 2010). Minchington provides compelling 
reason for such alignment in claiming that the total portfolio of brands needs to be aligned in organisational strategy as each brand subset has an impact on the other, and the essence of the corporate and consumer brand should be reflected in the essence of the employer brand to ensure consistency in delivery on the portfolio of brand promises. Such consistency, according to Barrow and Mosley (2005), is essential for a brand as this helps to deliver trust and confidence for the relevant stakeholder as well as clarity of purpose and positioning.

The synthesis in linkage between research findings and the literature review supports the fourth proposition (P4) and suggests consistency in the portfolio of brands influences the employer brand.

\section{Communication}

Research findings indicated that the communication of employer brand messages was key in order to positively impact employer brand perception (Bowd, 2006; Knox \& Bickerton, 2008), however, remained one of the top three challenges in managing employer brand (Kapoor, 2010). Watson Wyatt (2005) found that organisations who are highly effective communicators experienced strong employer brand strength, high levels of engagement and 20\% lower turnover rates than their peers. The mentioned findings are affirmed by Miles and Mangold (2004) whose conceptual model illustrated the importance of consistently delivering the employer brand message at all the employee touch points.

The aforementioned findings were reiterated in the literature which found that the employer brand communication should reflect honest, authentic and consistent employer brand messages about employment promises which could be delivered upon through an organisation's employer branding (people management) practices, and that the channelling of the employer brand message should be carefully considered to ensure messages attract targeted talent (Backhaus \& Tikoo, 2004; Bhattacharya, 2009; Duraturo, 2010; Minchington, 2010). Reiteration in the linkage between research findings and relevant literature supports the fifth proposition (P5) and proposes that communication influences the employer brand.

\section{Metrics}

Based on the implementation of an HR scorecard in a large organisation, Higgins (2010) found the measuring of HR employer branding efforts are required to ensure an effective employer brand that delivers on the employer brand promise.

The above mentioned finding was reiterated in literature that found value adding metrics has the potential to support delivery on the employer brand promise (Fernon, 2008; Lockwood, 2006; Minchington, 2010). The synthesis in linkage between the study and the literature review supports the sixth proposition (P6) and suggests that employer branding metrics influence the employer brand.

\section{Employer brand predictive model}

The purpose of this study was to explore the current state of knowledge about employer brand and to identify employer brand building blocks that can be integrated in an employer brand predictive model that will predict talent attraction and retention after being empirically validated.

During the initial literature overview key employer brand concepts were isolated due to researchers' significance attributed to these concepts in relation to talent attraction and retention. These employer brand concepts were refined to the following keywords: target group needs and/or segmentation, differentiated EVP, people management strategy, brand consistency, employer brand communication and HR employer branding metrics. These keywords were used to inform a comprehensive literature review that resulted in six propositions. Thereafter these same keywords were applied to guide research that would either support or reject the propositions.

Given the fact that the research findings reiterated the stated propositions, these propositions served as a guide to determine the following building blocks of an employer brand predictive model that can be empirically validated to effectively predict talent attraction and retention, and contribute to favourable positioning in the quest for talent:

- Target group needs

- EVP Differentiation

- People strategy

- Brand consistency

- Employer brand communication

- Employer branding metrics.

Figure 1 depicts an Employer Brand Predictive Model. The model is informed by the aforementioned employer brand building blocks based on their significance relative to employer brand which in turn influences talent attraction and retention.

The model presented in Figure 1 is theoretical in nature and a form of inductive reasoning, or conceptual explication, was used to search for linkages between theoretical concepts. Even though there is criticism of inductive reasoning because of its qualitative nature, it remains one of the most powerful methods to construct conceptual models and build new theories, without which science cannot make progress (Mouton, 2001). As stated in a previous section of this study, theoretical models allow one to make predictive claims under certain conditions, and bring conceptual coherence to a domain of science thereby simplifying our understanding of the world (Mouton, 2001). The employer brand predictive model limited, isolated, simplified and systematised the employer brand domain that was investigated, thereby adding value to scientific progress though the accurate representation of a set of phenomena, and propositions, which can be empirically tested. 


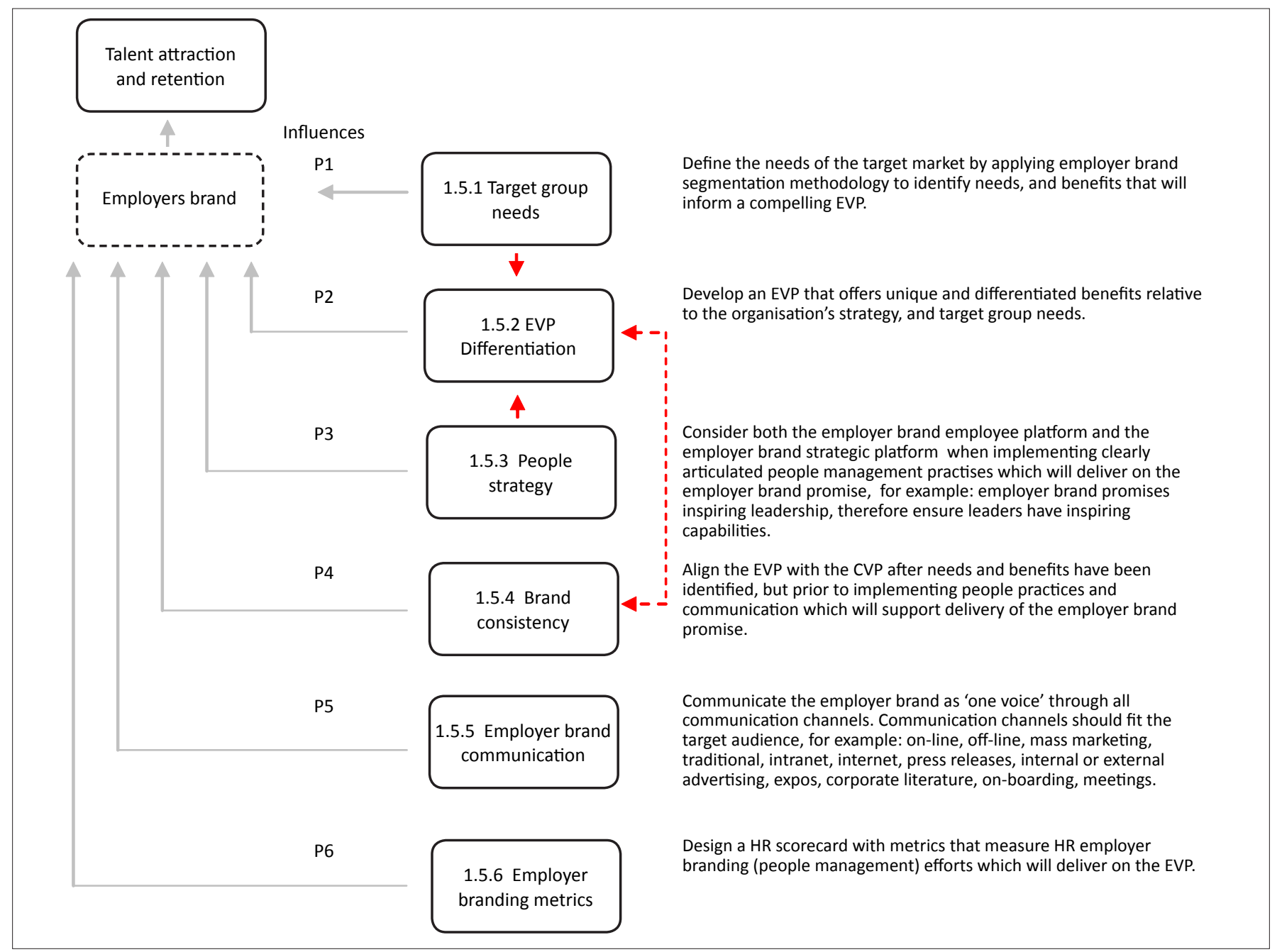

P1 - P6, Proposition 1 - Proposition 6; EVP, Employee Value Proposition; CVP, Customer Value Proposition; HR, human resources.

FIGURE 1: Employer Brand Predictive Model Theoretical implications.

\section{Managerial implications}

Even though the true practical contribution of the study will reveal itself once the effect of the employer brand predictive model on talent attraction and retention has been empirically validated, it is suggested that the employer brand predictive model (Figure 1) serves as an operational management model. The model provides a pointer relative to employer brand, and could guide managers and human resource functionaries in more effective talent attraction and retention decisions that could ultimately influence overall business performance.

The model contributes value in that it addresses key related employer brand building blocks; these building blocks represent an integrated approach which shapes and influences the total employer brand process.

\section{Limitations of the study and recommendations for future research}

This study set out to conceptually investigate building blocks of an employer brand predictive model, and to understand how these building blocks integrate to form a conceptual coherence that depicts employer brand relative to talent attraction and retention. Given the aim of this study, three main limitations have been identified, each of which provides opportunities for further research in this area. These are as follows.

Firstly, keywords used to guide the extraction of relevant research could have contributed to omitting published research. Secondly, a selective approach to data location could have also limited data gathering as additional research data may have been found by considering data sources other than Emerald, EBSCOhost and SAePublications, academic libraries, database searches including professional organisations such as CLC, Deloitte LLP, Employer Brand International (EBI) and Collective Learning Australia (CLA), as well as the UJ web portal that was used to trace and extract relevant data from electronic research journals including master's theses and doctorate dissertations.

A last limitation of this study is that the presented model has not been subject to empirical testing. Different propositions as diagrammatically depicted in Figure 1 suggest relationships between variables. These propositions can be assessed and empirically tested during future research. 
As stated previously in this article, there is relatively little scientific research available on employer brand practices relative to talent attraction and retention. The quest to win the talent war and remain sustainable in a shrinking global economy necessitates further studies to expand the depth of empirical theory on this topic and on the predictive capacity of the presented model.

\section{Conclusion}

This study was embedded in the search for linkages between theoretical concepts, and allowed the researcher to make predictive claims and bring conceptual coherence by explaining links between propositions. The aim was to determine building blocks of an employer brand predictive model and understand how these building blocks integrate to form a conceptual coherence that depicts employer brand relative to talent attraction and retention.

The research results reiterate the initial literature review findings. Based on the research which was obtained through various data sources, the results of this study emerged with six building-blocks that have linkages to employer brand, as well as talent attraction and retention. The results imply that the employer brand process requires an integrated approach where all of the building blocks are considered equally important when shaping the employer brand, or the organisation's differentiated attractiveness, in an effort to attract and retain talent

\section{Acknowledgements Competing interests}

The authors declare that they have no financial or personal relationship(s) which may have inappropriately influenced them in writing this article.

\section{Authors' contributions}

A.B. conducted the review of the literature and wrote the article as part of her master's thesis. L.d.S. was the cosupervisor who guided A.B. during the research. M.B. was the supervisor who ultimately took accountability for the successful production of the article.

\section{References}

Ambler, T., \& Barrow, S. (1996). The employer brand. Journal of BrandManagement, 4(3), 185-206.

Armstrong, M. (2007). Employee reward management and practice. London: Kogan Page Limited.

Backhaus, K., \& Tikoo, S. (2004). Conceptualizing and researching employer branding. Career Development International, 9, 501-517. http://dx.doi. org/10.1108/13620430410550754

Barrow, S., \& Mosley, R. (2005). The employer brand: Bringing the best of brand management to people at work. New York: John Wiley \& Sons.

Berthon, P., Ewing, M., \& Hah, L. (2005). Captivating company: Dimensions of attractiveness in employer branding. International Journal of Advertising, 24(2), 151-172.

Bhattacharya, P. (2009). Do you know your employer brand? Retrieved September 05, 2010, from http://www.employerbrandingonline.com/articles/strategy/124-doyou-know-your employer-brand.html

Blanchard, M. (2007). The next generation of workers. San Diego, California: The Ken Blanchard Companies.
Boshard, D., \& Louw, A. (2010). Talent - Trends Impacting its Availability and What Business Should Do About It. Retrieved March 11, 2011, from http://www. Business Should Do About It. Retrieved March 11, 2011,
humancapitalreview.org/content/default.asp?Article_ID=943

Bowd, W. (2006). Hudson employment branding. Australia, Brisbane: Hudson.

Boyd, G., \& Sutherland, M. (2005). Obtaining employee commitment to living the brand of the organisation. South African Journal of Business Management, 37(1) 9-20.

Brand Learning. (2009). Employee Value Propositions: A Key Marketing Tool for Talent Management. Retrieved October 05, 2010, from http://www.brandlearning.com/ UploadedDocuments/Employee-Value-Propositions.pdf

Bussin, M. (2007). New employee retention challenges. Finweek, 40, 46.

CareerBuilder. (2008). Employment Branding: Defining and Delivering your Employment Promise. Retrieved January 19, 2011, from http://img.icbdr.com/ images/jp/content/whitepapers/WPR-0026_Branding2.pdf

Charest, J. (2011). Global Talent Risk - Seven Responses. Retrieved February 18, 2011 from http://3.weforum.org/docsPS_WEF_GlobalTalentRisk_Report_2011.pdf

Cheese, P., Thomas, R.J., \& Craig, E. (2007). The talent powered organization: Strategies for globalization, talent management and high performance. London: Kogan Page Limited.

Cooper, P.S., \& Schindler, D.R. (1998). Business research methods. (7th edn.). New York: McGraw-Hill.

Corporate Leadership Council. (2002). Employee preferences survey. Washington DC: The Corporate Advisory Board.

Corporate Leadership Council. (2007). Leveraging Total Rewards to Attract and Retain In-Store employees. Retrieved April 20, 2010, from http://www. corporateleadershipcouncil.com

Crous, S. (2007). Talent makes the rules now. Corporate Research Foundation, 33, 4-7.

Dell, D., Ainspan, N., Bodenberg, T., Troy, K., \& Hickey, J. (2001). Engaging Employees Through Your Brand. The Conference Board, Research Report No. 1288-01-RR New York.

Deloitte Consulting LLP. (2008). 14th Annual Top Five Total Rewards Priorities Survey. Washington DC: Deloitte LLP.

Deloitte Consulting LLP. (2010). Talent Edge 2020: Blueprints for the new normal. Retrieved August 11, 2011, from http://www.deloitte.com/ assets/Dcom-UnitedStates/Local\%20Assets/Documents/IMOs/Talent/us talentedge2020_121710.pdf

Donath, B. (2001). Branding works for Internal Audience too. Marketing News, 35, 7.

Duraturo, C. (2010). Employer Branding Step 3: Communication. Retrieved August 02 , 2010, from http://www/carloduraturo.com/2010/01/employer-branding-step-3communication.htm

Edwards, M. (2005). Employer branding: HR or PR? (4th edn.). Oxford: Blackwell.

Fernon, D. (2008). Maximising the power of the employer brand. Admap, 4, 49-53.

Fraser, T. (2009, October). Wits Business School Open Day Presentation: The role of leadership in the delivery of the brand promise. Johannesburg: WITS University.

Freeman, C., \& Knox, S. (2006). Measuring and managing employer brand image in the service industry. Journal of Marketing Management, 22, 695-716. http://dx.doi. org/10.1362/026725706778612103

Gapp, R., \& Merrilees, B. (2006). Important factors to consider when using internal branding as a management strategy: A healthcare case study. Journal of Brand Management, 14(2), 162-176. http://dx.doi.org/10.1057/palgrave.bm.2550058

Glen, C. (2007). Fostering talent opportunity: Getting past first-base. Strategic Direction, 23(10), 3-5.

Hallén, H. (2007). Finding the right kind of talent. Wealth Management: Second Quarter, 11-15.

Higgins, N. (2010). What gets measured gets done: Developing a HR Scorecard. Retrieved July 07, 2010, from http://www.watsonwyatt.com/europe/

Hodes Global Network. (2006). Global Employer Brand Study: A two-phase research initiative among HR professionals from 25 countries. New York: Bernard Hodes Group.

Hughes, J., \& Rog, E. (2008). Talent Management: A strategy for improving employee recruitment, retention and engagement within hospitality organisations. International Journal of Contemporary Hospitality Management, 20(7), 743-757. http://dx.doi.org/10.1108/09596110810899086

Ingham, J. (2006). Closing the talent management gap. Strategic HR Review, 5(3), 20-24. http://dx.doi.org/10.1108/14754390680000877

Jenner, S., \& Taylor, S. (2007). Employer branding - Fad or the future for HR? Chartered Institute of Personnel and Development. Retrieved August 05, 2010, from http:// www.cipd.co.uk/NR/rdonlyres/56C8377F-256B-4556-8650-8408B0E07576/0/ empbrandlatfad.pdf

Jordaan, W. (2007). The Generation of Scientifically Sound Knowledge Objects. Capacity Building Workshop: 09 June, 2007. Presented by Professor Wilhelm Jordaan at the University of Johannesburg, South Africa.

Kapoor, V. (2010). Employer Branding: A Study of Its Relevance in India. The IUP Journal of Brand Management, 7, 51-75.

Kgobe, F.H. (2010). Exploring the significance of employer brands in the attraction and retention of talent for South African organisations. Unpublished MBA thesis, Gordon Institute of Business Science, University of Pretoria, South Africa.

King, C., \& Grace, D. (2008). Internal branding: Exploring the employee's perspective. Journal of Brand Management, 15(5), 358-372. http://dx.doi.org/10.1057/ palgrave.bm.2550136 
Kotler, P. (2007). Marketing Management. (12th edn.). New Jersey: Prentice Hall Publishers.

Knox, S., \& Bickerton, D. (2008). The six conventions of corporate branding. European Journal of Marketing, 37(78), 998-1016.

Knox, S., \& Maxwell, R. (2009). Motivating employees to live the brand. Journal of Marketing Management, 25, 893-907.

Kochanski, J.T. (2004). How business operating models drive talent development. World at Work Journal, Third Quarter, 26-33.

Lawler, E.E. (2000). Rewarding Excellence. San Francisco: Jossey-Bass Publishers.

Leonardi, C. (2007a). Skills management becomes a key strategic imperative. Gordon Institute of Business Science Review, 10, 1-4.

Leonardi, C. (2007b). Global business is playing talent management catch-up. Gordon Institute of Business Science Review. Retrieved April 05, 2008, from http://www. gobs.co.za/home.asp

Lloyd, S. (2002). Branding from the inside out. BRW, 24(10), 64-66.

Lockwood, N. (2006). Maximizing Human Capital: Demonstrating HR value with Key Performance Indicators. Retrieved November 10, 2010, from http://www.brock. $\mathrm{dk}$ / fileadmin/user_upload/brock/pdf/kursusafd/SHRM/Maximizing_Human Capital.pdf

Martin, G. (2007). Employer branding - Time for some long and 'hard' reflections. Chartered Institute of Personnel and Development. Retrieved August 05, 2010, from http://www.cipd.co.uk/NR/rdonlyres/56C8377F-256B-4556-86502010, from http://www.cipd.co.uk/
8408B0E07576/0/empbrandlatfad.pdf

McClelland, D.C. (1961). Methods of measuring human motivation. New York: Van Nostrand.

McKinsey Quarterly. (2005). Using branding to attract talent. Retrieved August 10, 2011, from http://mkqpreview2.qdweb.net/Marketing/Branding/Using branding to attract talent 1645

McKinsey Quarterly. (2006). Making talent a strategic priority. Retrieved April 05 2010, from http://www.psycheselling.com/Talent.pdf

Michaels, E., Handfield-Jones, H., \& Axelrod, B. (2001). The war for talent. Boston: Harvard Business School Press.

Miles, S., \& Mangold, G. (2004). A Conseptualization of the Employee Branding Process. Journal of Relationship marketing, 3(2/3), 65-87. http://dx.doi. org/10.1300/J366v03n02_05

Milkovich, G.T., \& Newman, J.M. (2008). Compensation. New York: McGraw-Hill/Irwin.

Minchington, B. (2006). Your employer brand. Torrensville: Hyde Park Press.

Minchington, B. (2010). The employer brand manager's handbook: Torrensville: Collective Learning.

Mohaptra, D. (2005). Kicking retention strategies into high gear. Retention Strategy Journal Tata Group, 29, 1-6.

Moroko, L., \& Uncles, M. (2009, March). Employer Branding. Wall Street Journal, R7R8.

Moroko, L., \& Uncles, M. (2009). Employer branding and market segmentation Retrieved October 05, 2010, http//www.palgrave-journals.com/bm/journal/v17/ n3/.../bm200910a.htm

Mosley, R.W. (2007). Customer experience, organisational culture and the employer brand. Journal of Brand Management, 15(2), 123-132.

Mortensen, R.M. (2010). Employer branding \& talent relationship management Unpublished Master's thesis, Aarhus School of Business, Aarhus University, Denmark.
Mouton, J. (2001). How to succeed in your master's and doctoral studies: A South African guide and resource book. Pretoria: Van Schaik.

Munsamy, M., \& Bosch Venter, A. (2009). Retention factors of management staff in the maintenance phase of their careers in local government. SA Journal of Human resource Management/SA Tydskrif vir Menslikehulpbronbestuur, 7(1), 1-9.

Personnel Today. (2008). Talent Management defined for Today and Tomorrow: A Guide to talent Management for Now and 2010. Retrieved April 05, 2008, from http://www. personneltoday.com/articles/2008/01/25/44093/getfeedback-3treport-talent-management.htm

Prinsloo, K. (2008). Managing people for Competitive Advantage. Master's Curriculum in Leadership, Performance and Change. Johannesburg: University of Johannesburg.

Punjaisri, K., \& Wilson, A. (2007). The role of internal branding in the delivery of the employee brand promise. Journal of Brand Management, 15(1), 57-70. http:// dx.doi.org/10.1057/palgrave.bm. 2550110

Purkayastha, F.R. (2006). SABMILLER's human capital proposition: institutionalizing a performance culture. Case Study: ICFAl Center for Management and Research. Retrieved February 05, 2010, from http://www.aabschools.com/case studies/476.html

Rosethorn, H. (2009). The employer brand - Keeping faith with the deal. Farnham: Gower Publishing Limited.

Sartain, L., \& Schumann, M. (2006). Brand from the inside: Eight essentials to emotionally connect your employees to your business. San Francisco: Jossey-Bass.

Schumann, M. (2006). You are how you brand. Communication World. July - August 29-31.

Sutherland, M., \& Karg, R. (2002). Employer of choice branding for knowledge workers. South African Journal of Business Management, 33(4), 13-20.

Torraco, R.J. (1997). Theory-Building Research Methods. In R.A. Swanson \& E.F. Holton III (Eds.), Human Resource Development: Research Handbook (pp. 114-137). San Francisco: Berrett-Koehler.

Tüzüner, V.L., \& Yüksel, C.A. (2009). Segmenting potential employees according to firm's employer attractiveness dimensions in the employer branding concept. Journal of Academic Research in Economics, 1, 46-61.

Walker, P. (2007). How to develop an effective employer brand. People Management, 13(21), 44-45.

Watson Wyatt. (2005). Maximizing the return on your human capital investment Human Capital Index Report. Retrieved July 07, 2010, from http://www. watsonwyatt.com

Welman, J.C., \& Kruger, S.J. (2001). Research methodology. Cape Town: Oxford University Press.

Wilden, R.M., Gudergan, S., \& Lings, I.N. (2010). Employer branding: Strategic implications for staff recruitment. Journal of Marketing Management, 26(1), 56-73.

Willard, J. (2010). Activating brand culture: Rethinking the internal communications platform. Retrieved July 08, 2010, from http://www.hrmreport.com/article/ Activating-Brand-Culture-Rethinking-the-Internal-Communications-Platform/

Willock, R. (2005, 17 May). Employer branding is key in fight for talent. Personnel Today, p. 4.

WorldatWork. (2007). The WorldatWork handbook of compensation, benefits and total rewards. Hoboken, New Jersey: John Wiley \& Sons, Inc.

Zingham, P.K., \& Schuster, J.R. (2000). Pay people right. San Francisco: Jossey-Bass Publishers. 